\title{
ANALISIS POTENSI PEMANENAN AIR HUJAN DALAM PEMENUHAN KEBUTUHAN AIR BERSIH DI KECAMATAN BANJARBARU UTARA
}

\author{
Nia Ridha Ramadhayanti ${ }^{1 *}$, Noordiah Helda ${ }^{2}$ \\ 1) Universitas Lambung Mangkurat Banjar Baru (email : $1610811120029 @$ mhs.ulm.ac.id) \\ 2) Universitas Lambung Mangkurat Banjar Baru (email : noordiah.helda@ulm.ac.id)
}

\section{$\underline{\text { Info Artikel }}$}

Riwayat Artikel:

Dikirim :26-04-2021

Direvisi : 17-06-2021

Diterbitkan : 28-06-2021

Keywords :

Rainwater Harvesting Air Hujan

Pemanenan Air Hujan

\section{$\underline{\text { ABSTRAK }}$}

Banjarbaru Utara merupakan salah satu kecamatan di kota Banjarbaru, Provinsi Kalimantan Selatan yang pertumbuhan penduduknya dalam lima tahun terakhir terus mengalami peningkatan. Bertambah pesatnya pertumbuhan penduduk di wilayah Banjarbaru Utara membuat perubahan fungsi tata guna lahan menjadi tidak terkontrol, di mana seharusnya fungsi kawasan yang dapat menjadi lahan resapan air dalam jumlah besar akhirnya semakin sedikit, sehingga jumlah air yang masuk ke dalam tanah untuk mengganti air tanah yang keluar menjadi berkurang. Sedangkan permintaan air bersih akan semakin bertambah. Penelitian ini bertujuan untuk mengetahui potensi pemanenan air hujan, untuk pemenuhan kebutuhan air bersih rumah tangga dan penggunaan air di Kecamatan Banjarbaru Utara. Metode yang digunakan untuk penelitian ini adalah metode Survei. Data yang digunakan adalah data primer dan data sekunder. Pada penelitian ini diperlukan beberapa analisis, seperti analisis hidrologi yang mencakup analisis curah hujan dengan metode Curah Hujan Andalan, untuk menghitung potensi pemanenan air hujan adalah dengan melakukan perkalian antara luas penampang atap bangunan, koefisien runoff, dan curah hujan di Kecamatan Banjarbaru Utara, dan dibantu dengan program QGIS 10.13 untuk memperoleh data luasan atap pada lokasi penelitian. Dari hasil penelitian didapatkan luas total luasan atap bangunan/rumah di Kecamatan Banjarbaru Utara sebesar $858.850 \mathrm{~m}^{2}$ dari 8.805 rumah dengan curah hujan harian andalan didapatkan $6,4 \mathrm{~mm} /$ hari serta koefisien runoff sebesar 0,8 . Dari hasil perhitungan didapatkan hasil potensi pemanenan air hujan sebesar 1.318.781.352 liter/tahun atau sama dengan 1.318.781,35 m³/Tahun. Berdasarkan survei wawancara responden didapatkan hasil penggunaan air bersih rata - rata sebesar 200 liter/orang/hari. Hasil pengolahan data berdasarkan jumlah penduduk dan penggunaan air bersih rata - rata, maka didapatkan hasil penggunaan air bersih sebesar 4.155.073.297,9 liter/tahun atau sama dengan 4.155.073,29 $\mathrm{m}^{3} /$ tahun. Dari hasil pengolahan data tersebut dapat disimpulkan bahwa potensi pemanenan air hujan tidak bisa memenuhi kebutuhan air bersih secara keseluruhan. Ketersediaan air berdasarkan potensi pemanenan air hujan ini secara tidak langsung juga dipengaruhi oleh pola perilaku masyarakat dalam memanfaatkan air dalam kebutuhan sehari - hari.

\section{PENDAHULUAN}

1.1 Latar Belakang

Banjarbaru Utara merupakan salah satu

kecamatan di kota Banjarbaru, Provinsi

Kalimantan Selatan yang pertumbuhan penduduknya dalam lima tahun terakhir terus mengalami peningkatan. Kecamatan Banjarbaru Utara terdiri dari 4 kelurahan yaitu Loktabat Utara, Mentaos, Komet dan Sungai Ulin. Bertambah pesatnya pertumbuhan penduduk di wilayah Banjarbaru Utara membuat perubahan 
fungsi tata guna lahan menjadi tidak terkontrol, di mana seharusnya fungsi kawasan yang dapat menjadi lahan resapan air dalam jumlah besar akhirnya semakin sedikit, sehingga jumlah air yang masuk ke dalam tanah untuk mengganti air tanah yang keluar menjadi berkurang. Sedangkan, di lain sisi permintaan air bersih akan semakin bertambah.

Banjarbaru Utara adalah salah satu kecamatan di Kota Banjarbaru yang penduduknya memanfaatkan air tanah dangkal untuk pemenuhan kebutuhan sehari - hari (Kurdi et al, 2018). Pengambilan air tanah yang berlebihan yang diperparah oleh meningkatnya konversi lahan menjadi areal pemukiman, perkantoran, maupun komersial akan memicu terjadinya kelangkaan air tanah. Dalam kondisi seperti ini, alternatif sumber air seperti pemanfaatan air hujan perlu dipertimbangkan sebagai pilihan menarik yang murah, sehingga dapat mengurangi konsumsi air bersih (portable water) (Zhang et al., 2009). Berdasarkan latar belakang masalah tersebut, maka pada penelitian ini dilakukan perancangan Pemanenan Air Hujan (Rainwater Harvesting) dengan Teknik Pemanenan Air Hujan dengan Atap atau Bangunan (roof top rain water harvesting), untuk pemenuhan kebutuhan air bersih pada Kecamatan Banjarbaru Utara.

\subsection{Perumusan Masalah}

Adapun Perumusan Masalah adalah sebagai berikut:

1. Berapa jumlah kebutuhan air bersih untuk kebutuhan rumah tangga masyarakat pada Kecamatan Banjarbaru Utara?

2. Bagaimana potensi penggunaan Pemanenan Air Hujan untuk pemenuhan kebutuhan air bersih pada Kecamatan Banjarbaru Utara?

3. Bagaimana perbandingan jumlah potensi air hujan yang dapat dipanen dengan kebutuhan air bersih untuk rumah tangga di Kecamatan Banjarbaru Utara?

\subsection{Tujuan Penelitian}

Adapun tujuan dari penelitian yang akan dicapai adalah sebagai berikut:

1. Menganalisis jumlah kebutuhan air bersih untuk kebutuhan rumah tangga masyarakat pada Kecamatan Banjarbaru Utara.

2. Menganalisis potensi penggunaan Pemanenan Air Hujan untuk pemenuhan kebutuhan air bersih pada Kecamatan Banjarbaru Utara.

3. Membandingkan jumlah potensi air hujan yang dapat dipanen dengan kebutuhan air bersih untuk rumah tangga di Kecamatan Banjarbaru Utara.

\section{METODE PENELITIAN}

\subsection{Lokasi Penelitian}

Lokasi Penelitian terletak di Kecamatan Banjarbaru Utara, Kota Banjarbaru, Kalimantan Selatan. Kecamatan Banjarbaru Utara secara geografis terletak pada posisi antara $03^{\circ} 27^{\prime}$ $03^{\circ} 29^{\prime}$ LS - $114^{\circ} 45^{\prime}$ - $114^{\circ} 48^{\prime}$ BT. Secara Topografi, Kota Banjarbaru memiliki topografi bervariasi antara $\pm 0 \mathrm{~m}-500 \mathrm{~m}$ dari permukaan laut (dpl); dengan bentuk bentang alam (morfologi) yang cukup variatif (beragam). Sebagian besar wilayah Kota Banjarbaru berada di ketinggian 7 - 25 mdpl yaitu sekitar 10.615 $\mathrm{Ha}$ atau 33,23\% dari luas Kota Banjarbaru. Kecamatan Banjarbaru Utara terdiri dari 4 kelurahan yaitu Loktabat Utara, Mentaos, Komet dan Sungai Ulin, Kecamatan Banjarbaru Utara memiliki luasan wilayah mencapai $\pm 24,44 \mathrm{Km}^{2}$ atau $6,58 \%$ dari luas wilayah Kota Banjarbaru.

\subsection{Pengumpulan Data}

Beberapa data yang akan digunakan adalah Data Primer yang diperoleh dari Wawancara dan survei langsung ke lokasi penelitian, berupa Data penggunaan air bersih di dalam satu rumah tangga, luasan atap rumah di lokasi penelitian, informasi sumber air bersih rumah tangga di lokasi penelitian, tata guna lahan disekitar rumah dan kondisi lahan: ditutupi rumput, semen, atau bebatuan. Data Sekunder berupa data curah hujan harian diperoleh dari BMKG (Stasiun Klimatologi Banjarbaru), data peraturan $\mathrm{PAH}$, data statistik penduduk Banjarbaru Utara dari Badan Pusat Statistik Kota Banjarbaru dan data luasan atap dengan penggunaan QGIS.

\subsection{Pengolahan Data}

\subsubsection{Pemanenan Air Hujan}

Pemanenan Air Hujan (Rainwater Harvesting) dalam arti luas dapat didefinisikan sebagai proses mengumpulkan Run-off atau aliran hujan untuk pasokan kebutuhan air domestik, pertanian, dan pengelolaan lingkungan. (Worm \& Hattum, 2006). Sistem rainwater harvesting terdiri dari 3 komponen dasar yang penting. 
Antara lain: Penangkap atau permukaan atap yang berfungsi untuk menangkap air hujan, Sistem pengiriman untuk memindahkan air hujan yang sudah ditangkap dari penangkap atau permukaan atap ke bak penyimpanan dan Bak penyimpanan atau tangki air untuk menyimpan air hingga air itu dipergunakan.

Atap bangunan merupakan pilihan area penangkapan air hujan. Jumlah air yang dapat ditampung dari sebuah atap tergantung dari material atap tersebut, di mana semakin halus permukaan atap maka akan semakin baik untuk proses penangkapan air hujan tersebut. Luas atap bangunan dan perhitungan curah hujan yang didapatkan dari Stasiun BMKG digunakan untuk menentukan perhitungan terhadap curah hujan yang dapat ditampung. Menurut Maryono (2017), jumlah air hujan yang dapat dipanen menggunakan rumus sebagai berikut:

$$
\Sigma Q=a \times R \times A
$$

Dimana:

$\Sigma \mathrm{Q}=$ Jumlah Air yang dapat dipanen $\left(\mathrm{m}^{3} /\right.$ Hari $)$

$\mathrm{a}=$ Koefisien $\operatorname{Runoff}(0,8)$

$\mathrm{R}=$ Curah Hujan Harian (m)

A $=$ Luas Atap Bangunan $\left(\mathrm{m}^{2}\right)$

Total kebutuhan air yang akan digunakan sebagai acuan adalah kebutuhan air per tahun. Untuk mengetahui jumlah tersebut didapati persamaan:

Kebutuhan Air = Rata-rata konsumsi air per orang $\mathrm{x}$

Jumlah Penghuni x 365 Hari

\subsubsection{Kebutuhan Air}

Kebutuhan air bersih adalah banyaknya air bersih yang harus tersedia untuk keperluan penduduk beserta sarana dan prasarananya, termasuk juga menentukan besarnya fluktuasi kebutuhan air bersih di masa yang akan datang. Kebutuhan air bersih dibedakan atas kebutuhan domestik dan non domestik. Kebutuhan Air Domestik adalah kebutuhan air yang digunakan pada tempat - tempat hunian pribadi untuk pemenuhan kebutuhan sehari - hari atau rumah tangga seperti untuk minum, memasak, mandi, cuci, menyiram tanaman, halaman dan pengangkutan air buangan (buangan dapur dan toilet). Satuan yang dipakai adalah liter/orang/hari. Kebutuhan Air Non Domestik adalah kebutuhan air bersih di luar keperluan rumah tangga.

\subsubsection{Proyeksi Jumlah Penduduk}

Angka pertumbuhan dalam suatu persen tersebut digunakan untuk memproyeksikan jumlah penduduk untuk beberapa tahun mendatang. Metode yang digunakan adalah metoda Aritmetical Increase:

$$
P n=P t[1+(n x P p \%)]
$$

Dimana:

Pn = Jumlah penduduk yang akan datang

$\mathrm{Pt}=$ Jumlah penduduk pada akhir tahun data

$\mathrm{Pp}=$ Kenaikan jumlah penduduk (\%)

$\mathrm{n}=$ Periode waktu yang ditinjau

\subsubsection{Curah Hujan Andalan}

Menurut Susana (2012), Curah hujan andalan merupakan curah hujan yang memiliki tingkat peluang untuk terjadi paling tinggi dimana pada periode tertentu yang peluang terjadinya mencapai $80 \%$. Perhitungan hujan andalan dilakukan melalui pengolahan data curah hujan bulanan yang ada dengan mengurutkan peringkat data curah hujan berdasarkan besar curah hujan rata - ratabulanan. Lalu diperhitungkan peluang masing - masing dengan rumus:

$$
\mathrm{P}(\%)=\left(\frac{m}{n+1}\right) \times 100 \%
$$

Dimana:

$\mathrm{P}(\%)=$ Peluang curah hujan $(\%)$

$\mathrm{m}$ = rangking data curah hujan

$\mathrm{n} \quad=$ Jumlah data curah hujan

\section{HASIL DAN PEMBAHASAN}

\subsection{Ketersediaan Air}

Ketersediaan air yang dimaksud dalam perencanaan ini adalah air hujan yang dapat terkumpul di atap - atap rumah di Kecamatan Banjarbaru Utara.

\subsection{Data Curah Hujan}

Data curah hujan tahunan yang didapatkan dari BMKG Stasiun Klimatologi Banjarbaru, diurutkan dari curah hujan terbesar hingga terkecil lalu diperhitungkan dengan menggunakan penentuan hujan andalan. Hujan andalan merupakan besarnya curah hujan bulanan yang terjadi pada periode tertentu yang peluang terjadinya mencapai $80 \%$. Adapun contoh perhitungannya adalah sebagai berikut: 
a. Diketahui

$\begin{array}{ll}\text { Tahun } & =2010 \\ \mathrm{n} & =11 \\ \mathrm{~m} & =1\end{array}$

b. Peluang Hujan

$$
\begin{aligned}
& \mathrm{P}(\%)=\left(\frac{m}{n+1}\right) \times 100 \%=\left(\frac{1}{11+1}\right) \times 100 \%= \\
& 8,3 \%
\end{aligned}
$$

Untuk hasil perhitungan selanjutnya dapat dilihat dalam Tabel 1 berikut:

Tabel 1. Peluang Hujan berdasarkan Rangking

\begin{tabular}{cccc}
\hline Tahun & $\begin{array}{c}\text { Data Curah } \\
\text { Hujan } \\
\text { Maksimum } \\
\text { Tahunan }(\mathrm{mm})\end{array}$ & $\begin{array}{c}\text { Rangking } \\
(\mathrm{m})\end{array}$ & Peluang \\
\hline 2010 & 3362,2 & 1 & 8,3 \\
\hline 2020 & 3063,9 & 2 & 16,7 \\
\hline 2013 & 3006,1 & 3 & 25,0 \\
\hline 2017 & 2916,4 & 4 & 33,3 \\
\hline 2011 & 2897,4 & 5 & 41,7 \\
\hline 2012 & 2508,4 & 6 & 50,0 \\
\hline 2016 & 2466,7 & 7 & 58,3 \\
\hline 2018 & 2464,4 & 8 & 66,7 \\
\hline 2014 & 2351,2 & 9 & 75,0 \\
\hline 2019 & 1919,4 & 10 & 83,3 \\
\hline 2015 & 1712,9 & 11 & 91,7 \\
\hline
\end{tabular}

Setelah semua peluang ditentukan maka dipilih salah satu data yang paling mendekati peluang $80 \%$. Berdasarkan hasil perhitungan dapat dilihat bahwa curah hujan tahun 2019 memiliki peluang sebesar $83,3 \%$ sehingga data curah hujan yang nantinya akan digunakan untuk menentukan volume air hujan yang tersedia untuk Pemanenan Air Hujan. Data curah hujan tahun 2019 yang dapat dilihat pada Tabel 2 berikut:

Tabel 2. Curah Hujan Andalan

\begin{tabular}{cc}
\hline Bulan & Curah Hujan $(\mathrm{mm})$ \\
\hline Januari & 283,8 \\
\hline Februari & 350,4 \\
\hline Maret & 282,1 \\
\hline April & 322,1 \\
\hline Mei & 54,3 \\
\hline Juni & 146,1 \\
\hline Juli & 18,4 \\
\hline Agustus & 12,5 \\
\hline September & 0 \\
\hline Oktober & 59,3 \\
\hline November & 121,2 \\
\hline Desember & 269,2 \\
\hline
\end{tabular}

\subsection{Analisis Potensi Pemanenan Air Hujan} Analisis Potensi pemanenan air hujan dihitung berdasarkan Luasan Atap Bangunan di daerah penelitian. Pada penelitian ini berupa Luasan atap yang ada di Kecamatan Banjarbaru Utara. Luas Atap Bangunan/Rumah di Kecamatan Banjarbaru Utara didapatkan dari hasil interpretasi Shapefile Persil Bangunan dari Website Geofabrik menggunakan Aplikasi Qgis. Luasan atap di setiap Kelurahan di Kecamatan Banjarbaru Utara dibedakaan berdasarkan tipe luasan atap dengan luasan $50 \mathrm{~m}^{2}, 75 \mathrm{~m}^{2}, 125 \mathrm{~m}^{2}$, $175 \mathrm{~m}^{2}$ dan $200 \mathrm{~m}^{2}$ yang dapat dilihat pada Tabel 3 dan Tabel 4 berikut: 


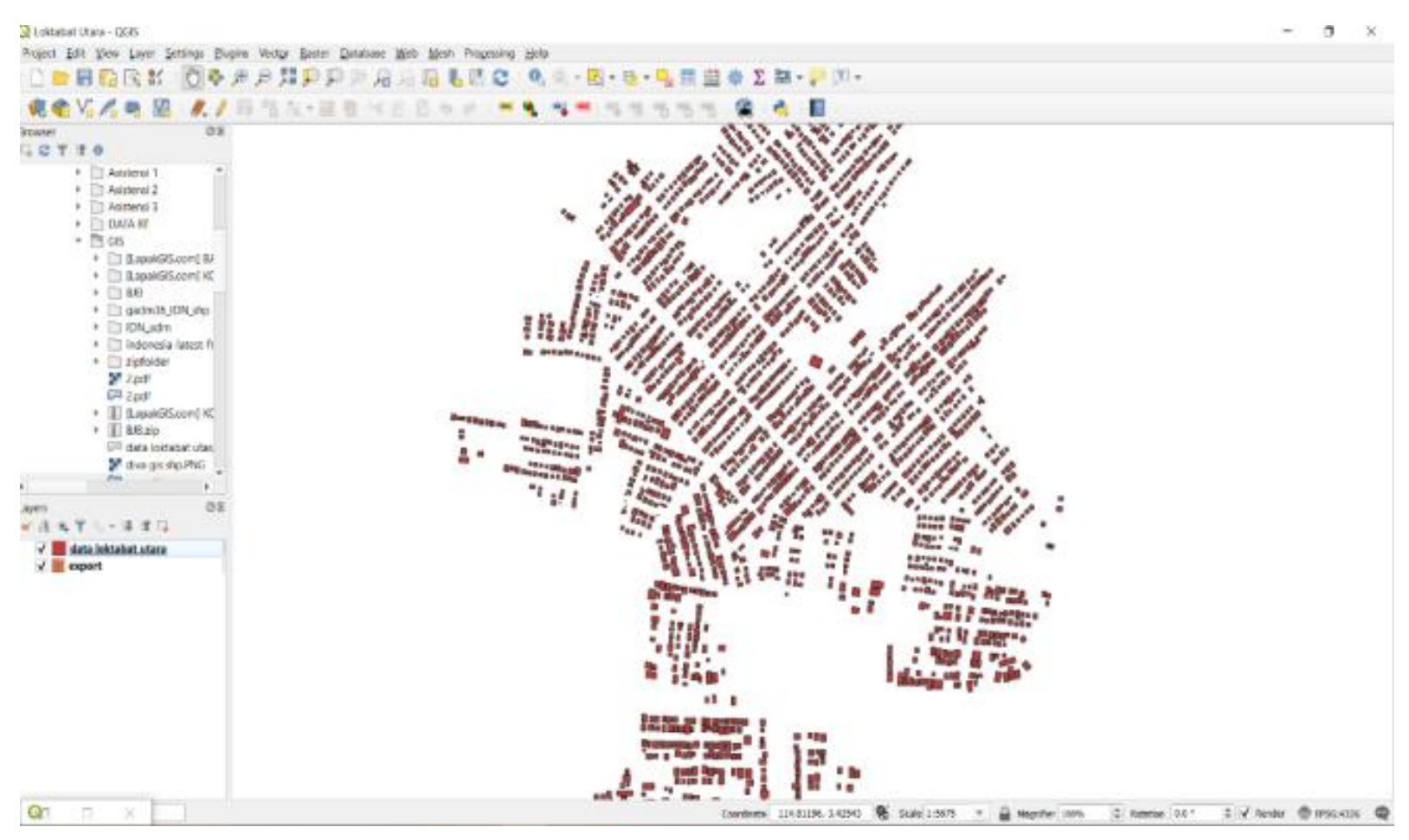

Gambar 1. Shapefile Persil Kelurahan Loktabat Utara

Tabel 3. Jumlah Rumah Berdasarkan Tipe Luas Atap Bangunan/Rumah di Kecamatan Banjarbaru Utara

\begin{tabular}{llcccccr}
\hline \multirow{2}{*}{ No. } & \multirow{6}{*}{ Kelurahaan } & \multicolumn{5}{c}{ Jenis Atap Bangunan } & \\
\cline { 3 - 7 } & & Tipe 1 & Tipe 2 & Tipe 3 & Tipe 4 & Tipe 5 & \multirow{2}{*}{ Jumlah } \\
\cline { 2 - 6 } & $\pm 50 \mathrm{~m}^{2}$ & $\pm 75 \mathrm{~m}^{2}$ & $\pm 125 \mathrm{~m}^{2}$ & $\pm 175 \mathrm{~m}^{2}$ & $\pm 200 \mathrm{~m}^{2}$ & \\
\hline 1 & Sungai Ulin & 1.458 & 580 & 350 & 45 & 60 & 2.493 \\
\hline 2 & Komet & 151 & 128 & 212 & 64 & 99 & 654 \\
\hline 3 & Mentaos & 555 & 443 & 645 & 191 & 339 & 2.173 \\
\hline 4 & Loktabat Utara & 833 & 938 & 1.163 & 249 & 302 & 3.485 \\
\hline & Jumlah Total & 2.997 & 2.089 & 2.370 & 549 & 800 & 8.805 \\
\hline
\end{tabular}

Tabel 4. Luas, Jumlah dan Persentase Luas Atap Bangunan/Rumah di Kecamatan Banjarbaru Utara

\begin{tabular}{|c|c|c|c|c|c|c|c|c|}
\hline \multirow{3}{*}{ No. } & \multirow{3}{*}{ Kelurahaan } & \multicolumn{5}{|c|}{ Luas Atap Bangunan } & \multirow{3}{*}{$\begin{array}{c}\text { Jumlah } \\
\text { Luas } \\
\left(\mathrm{m}^{2}\right)\end{array}$} & \multirow{3}{*}{$\begin{array}{c}\text { Presentase } \\
(\%)\end{array}$} \\
\hline & & Tipe 1 & Tipe 2 & Tipe 3 & Tipe 4 & Tipe 5 & & \\
\hline & & $\pm 50 \mathrm{~m}^{2}$ & $\pm 75 \mathrm{~m}^{2}$ & $\pm 125 \mathrm{~m}^{2}$ & $\pm 175 \mathrm{~m}^{2}$ & $\pm 200 \mathrm{~m}^{2}$ & & \\
\hline 1 & Sungai Ulin & 72.900 & 43.500 & 43.750 & 7.875 & 12.000 & 180.025 & 20,96 \\
\hline 2 & Komet & 7.550 & 9.600 & 26.500 & 11.200 & 19.800 & 74.650 & 8,69 \\
\hline 3 & Mentaos & 27.750 & 33.225 & 80.625 & 33.425 & 67.800 & 242.825 & 28,27 \\
\hline \multirow[t]{2}{*}{4} & Loktal & 41.650 & 70.350 & & 43.575 & 60.400 & 361.350 & 42,07 \\
\hline & Jumlah Total & 149.850 & 156.675 & 296.250 & 96.075 & 160.000 & 858.850 & 100 \\
\hline
\end{tabular}

Dari tabel diperoleh luas total luasan atap bangunan/rumah di Kecamatan Banjarbaru Utara sebesar $858.850 \mathrm{~m}^{2}$ dari 8.805 rumah. Berdasarkan pengamatan saat melakukan Survei di daerah penelitian dimana Jenis Atap
Bangunan/Rumah di Kecamatan Banjarbaru Utara menggunakan Jenis Atap Genteng. Maka diasumsikan semua Jenis Atap Rumah untuk Perhitungan menggunakan atap Genteng. Maka, Koefisien Runoff berdasarkan Jenis Atap 
didapatkan angka 0,8 sebagai angka perkiraan, satu milimeter curah hujan yang jatuh di atas satu meter persegi atap akan menghasilkan air tampungan sebesar 0,8 Liter setelah mempertimbangkan kehilangan air oleh proses evaporasi dan kebocoran air lainnya.

\subsection{Analisis Jumlah Air Hujan yang dapat dipanen}

Perhitungan jumlah air hujan yang dapat dipanen dihitung dengan mengalikan jumlah air hujan yang dapat dipanen yang didapatkan dari hasil perhitungan curah hujan andalan di daerah penelitian, koefisien Run off sebesar 0,8 berdasarkan jenis atap dan luas atap bangunan berdasarkan jumlah luasan atap di tiap kelurahan. Hasil jumlah air yang dapat dipanen di Kecamatan Banjarbaru Utara dapat dilihat pada Tabel 5 Berikut:

Tabel 5. Debit Air Hujan yang Dapat Dipanen di Kecamatan Banjarbaru Utara

\begin{tabular}{ccc}
\hline Kelurahan & $\begin{array}{c}\text { Total Q } \\
\text { m3/Tahun }\end{array}$ & $\begin{array}{c}\text { Total Q } \\
\text { liter/tahun }\end{array}$ \\
\hline Sungai Ulin & $276.431,99$ & 276.431 .988 \\
\hline Komet & $114.626,57$ & 114.626 .568 \\
\hline Mentaos & $372.862,64$ & 372.862 .644 \\
\hline Loktabat Utara & $554.860,15$ & 554.860 .152 \\
\hline Jumlah & $1.318 .781,35$ & 1.318 .781 .352 \\
\hline
\end{tabular}

\subsection{Jumlah Kebutuhan Air Rumah Tangga/ Domestik di Kecamatan Banjarbaru Utara}

Survei lapangan dilakukan pada 40 Responden di Kecamatan Banjarbaru Utara, dengan pembagian 10 Responden di setiap Kelurahan. Penentuan Jumlah Responden menurut Sugiyono (2011), memberikan saran-saran tentang ukuran sampel untuk penelitian yang layak adalah antara 30 sampai dengan 500 . Dalam penelitian ini mengambil sampel atau wawancara pada responden sebanyak 40 orang. Survei lapangan dilakukan pada tanggal 16 November, 10 Desember, 13 Desember, 17 Desember dan 27 Desember 2020. Berdasarkan hasil Survei didapatkan penggunaan air untuk kebutuhan rumah tangga di setiap Kelurahan perhari di Kecamatan Banjarbaru Utara, dapat dilihat pada Tabel 6 Berikut:
Tabel 6. Rekapitulasi Hasil Kuisioner Kebutuhan Air Bersih di Kecamatan Banjarbaru Utara

\begin{tabular}{clccc}
\hline & & \multicolumn{3}{c}{$\begin{array}{c}\text { Kebutuhan akan air } \\
\text { (liter/orang/hari) }\end{array}$} \\
\cline { 3 - 5 } No. & Kelurahaan & Min & Max & Rata-Rata \\
\cline { 3 - 5 } & & 150 & 300 & 215 \\
\hline 1 & Sungai Ulin & 150 & 250 & 190 \\
\hline 2 & Komet & 150 & 250 & 200 \\
\hline 3 & Mentaos & 150 & 300 & 195 \\
\hline 4 & Loktabat Utara & & 200 \\
\hline \multicolumn{3}{c}{ Rerata } \\
\hline
\end{tabular}

Berdasarkan data BPS Kota Banjarbaru 2019 Jumlah penduduk di Kecamatan Banjarbaru Utara adalah sebanyak 56.039 Jiwa. Dengan terbagi pada Kelurahan Loktabat Utara sebanyak 23.012 Jiwa, Kelurahan Mentaos sebanyak 12.346 Jiwa, Kelurahan Komet sebanyak 5.261 Jiwa dan Sungai Ulin sebanyak 15.420 Jiwa. Jumlah Penduduk pada Tahun 2020 dapat dihitung dengan Proyeksi Jumlah Penduduk menggunakan rumus sebagai berikut:

$$
\begin{aligned}
& \mathrm{Pn}=\mathrm{Pt}[1+(\mathrm{n} \times \mathrm{Pp} \%)] \\
& \mathrm{Pn}=56.039[1+(1 \times 1,57 \%)] \\
& \mathrm{Pn}=56.919 \text { Jiwa }
\end{aligned}
$$

Berdasarkan rumus perhitungan Proyeksi Penduduk tersebut didapatkan Jumlah Penduduk di Kecamatan Banjarbaru Utara sebanyak 56.919 Jiwa. Jumlah penduduk per Kelurahan pada Tahun 2020 dapat dilihat pada Tabel 7 berikut:

Tabel 7. Jumlah Penduduk Kecamatan Banjarbaru Utara Tahun Proyeksi

\begin{tabular}{clc}
\hline No. & Kelurahan & Jumlah Penduduk Tahun 2020 \\
\hline 1 & Sungai Ulin & 15662 \\
\hline 2 & Komet & 5344 \\
\hline 3 & Mentaos & 12540 \\
\hline 4 & Loktabat Utara & 23373 \\
\hline
\end{tabular}

Kebutuhan Air rumah tangga/domestik di Kecamatan Banjarbaru Utara dihitung dengan mengalikan jumlah penduduk dengan kebutuhan air rata-rata rumah tangga/domestik. Kebutuhan air rumah tangga/domestik per Kelurahan di Kecamatan banjarbaru Utara dapat dilihat pada Tabel 8 berikut: 
Tabel 8. Kebutuhan Air Rumah Tangga/Domestik per Kelurahan di Kecamatan Banjarbaru Utara

\begin{tabular}{clccccc}
\hline No. & Kelurahan & $\begin{array}{c}\text { Jumlah } \\
\text { Penduduk }\end{array}$ & $\begin{array}{c}\text { Penggunaan Air } \\
\text { (liter/hari) }\end{array}$ & $\begin{array}{c}\text { Penggunaan Air } \\
(\text { liter/tahun })\end{array}$ & $\begin{array}{c}\text { Penggunaan } \\
\text { Air }\left(\mathrm{m}^{3} / \text { hari }\right)\end{array}$ & $\begin{array}{c}\text { Penggunaan Air } \\
\left(\mathrm{m}^{3} / \text { tahun }\right)\end{array}$ \\
\hline 1 & Sungai Ulin & 15.662 & $3.132 .418,80$ & 1.143 .332 .862 & $3.132,42$ & $1.143 .332,86$ \\
\hline 2 & Komet & 5.343 & $1.068 .719,54$ & 390.082 .632 & $1.068,72$ & $390.082,63$ \\
\hline 3 & Mentaos & 12.539 & $2.507 .966,44$ & $915.407 .750,60$ & $2.507,97$ & $915.407,75$ \\
\hline 4 & Loktabat Utara & 23.373 & $4.674 .657,68$ & $1.706 .250 .053,20$ & $4.674,66$ & $1.706 .250,05$ \\
\hline & Jumlah & 56.919 & $11.383 .762,46$ & $4.155 .073 .297,90$ & $11.383,76$ & $4.155 .073,30$ \\
\hline
\end{tabular}

\subsection{Analisis Perbandingan Kebutuhan Pengunaan Air bersih dengan Jumlah Air hujan yang dipanen}

Penggunaan air bersih di Kecamatan Banjarbaru Utara adalah digunakan untuk beberapa aktivitas penggunaan air seperti: Untuk kegiatan mencuci,

wudhu, mandi, toilet, menyiram tanaman, mencuci kendaraan dan lain-lain.

Tabel 9. Jumlah Perbandingan Rerata Penggunaan Air dengan Jumlah Air yang Dapat Dipanen di Tiap Kelurahan

\begin{tabular}{clccc}
\hline No. & Kelurahan & $\begin{array}{c}\text { Jumlah } \\
\text { Penduduk }\end{array}$ & $\begin{array}{c}\text { Total penggunaan } \\
\text { air untuk kebutuhan masyarakat } \\
\text { (liter/tahun) }\end{array}$ & $\begin{array}{c}\text { Total air yang dipanen } \\
\text { (liter/tahun) }\end{array}$ \\
\hline 1 & Sungai Ulin & 15.662 & 1.143 .332 .862 & 276.431 .988 \\
\hline 2 & Komet & 5.344 & $390.082 .632,10$ & 114.626 .568 \\
\hline 3 & Mentaos & 12.540 & $915.407 .750,60$ & 372.862 .644 \\
\hline 4 & Loktabat Utara & 23.373 & $1.706 .250 .053,20$ & 554.860 .152 \\
\hline & Jumlah & 56.919 & $4.155 .073 .297,90$ & 1.318 .781 .352 \\
\hline
\end{tabular}

Tabel 10. Hasil Perbandingan Rerata Penggunaan Air dengan Jumlah Air yang dapat Dipanen di Tiap Kelurahan

\begin{tabular}{clcccc}
\hline No. & Kelurahaan & $\begin{array}{c}\text { Total penggunaan air } \\
\text { untuk kebutuhan } \\
\text { masyarakat (liter/tahun) }\end{array}$ & $\begin{array}{c}\text { Total air yang } \\
\text { dipanen } \\
\text { (liter/tahun) }\end{array}$ & $\begin{array}{c}\text { Presentase } \\
\text { Pemenuhan } \\
\text { Air Bersih (\%) }\end{array}$ & Keterangan \\
\hline 1 & Sungai Ulin & $1.143 .332 .862,00$ & 276.431 .988 & 24,18 & Tidak Memenuhi \\
\hline 2 & Komet & $390.082 .632,10$ & 114.626 .568 & 29,39 & Tidak Memenuhi \\
\hline 3 & Mentaos & $915.407 .750,60$ & 372.862 .644 & 40,73 & Tidak Memenuhi \\
\hline 4 & Loktabat Utara & $1.706 .250 .053,20$ & 554.860 .152 & 32,52 & Tidak Memenuhi \\
\hline
\end{tabular}

Potensi pemanenan air hujan di Kecamatan Banjarbaru Utara berdasarkan hasil perhitungan adalah sebesar 1.318.781.352 liter/tahun atau sama dengan 3.613,1 liter/hari. Jika diasumsikan apabila setiap rumah memiliki luas atap yang sama maka setiap rumah dapat menampung air hujan sebesar 149.776,42 liter/tahun atau 410,35 liter/hari. Hasil tersebut didapatkan melalui potensi pemanenan air hujan di Kecamatan Banjarbaru Utara dibagi dengan jumlah rumah di Kecamatan Banjarbaru Utara yaitu sebanyak 8.805 rumah.
Potensi pemanenan air hujan tersebut dihitung berdasarkan luas atap rumah setiap penduduk di Kecamatan Banjarbaru Utara yang di dapatkan dari hasil interpretasi melalui QGIS. Dari hasil perhitungan tersebut diketahui luas atap bangunan di Kecamatan Banjarbaru Utara sebesar $858.850 \mathrm{~m}^{3}$ dari 8.805 rumah. Mengacu pada Survei di lapangan terkait keadaan dan luas bangunan rumah di Kecamatan Banjarbaru Utara Sebagian besar sudah dalam keadaan baik dengan atap rumah sudah terbuat dari Genteng. 
Dengan kondisi tersebut seharusya pemanenan air hujan dapat dilakukan dengan maksimal. Kemudian berdasarkan data luasan atap tipe rumah di Kecamatan Banjarbaru Utara yang paling banyak adalah tipe 3 dengan luasan kurang lebih berkisar $125 \mathrm{~m}^{2}$ mencapai 2370 rumah. Hal tersebut dapat dianalisis bahwa rata - rata bangunan rumah di Kecamatan Banjarbaru Utara sudah dalam kondisi layak.

Setelah diketahui potensi pemanenan air hujan di Kecamatan Banjarbaru Utara, selanjutnya mencari penggunaan air rata - rata penduduk, yang dilakukan melalui Kuisioner yang diberikan kepada 40 responden di Kecamatan Banjarbaru Utara. Didapatkan rata - rata penggunaan air bersih per orang per hari sebanyak 200 liter/orang/hari. Macam penggunaan dari air bersih tersebut yaitu, mandi, mencuci alat - alat rumah tangga, mencuci pakaian, wudhu dan lain - lain. Perkiraan penggunaan air bersih rata-rata tersebut memungkinkan adanya Overestimate atau penaksiran yang terlalu tinggi, hal itu dapat dilihat dari penggunaan Air Domestik berdasarkan Standar Kebutuhan SNI 6728. 1:2015 untuk Kecamatan Banjarbaru dengan Standar Kota Kecamatan/Desa yang hanya berkisar antara 60-90 liter/orang/hari. Sama halnya jika berdasarkan standar Kota Banjarbaru dengan Jumlah Penduduk sebanyak 248.423 Jiwa yang termasuk dalam Kategori Kota Sedang maka standar pemakaian air bersih berkisar antara 100-125 liter/orang/hari. Sedangkan berdasarkan Ditjen Cipta Karya, Departemen PU Tahun 2006, pemakaian rata rata air bersih sebesar 144 liter/orang/hari.

Hasil dari pengolahan data yang berupa perbandingan antara volume air hujan yang dapat dipanen di Kecamatan Banjarbaru Utara dan penggunaan air bersih di Kecamatan Banjarbaru Utara secara keseluruhan, hasil air bersih dari pemanenan air hujan tersebut tidak bisa dijadikan satu - satunya sumber air bersih di Kecamatan Banjarbaru Utara. Potensi Pemanenan Air Hujan di Kecamatan Banjarbaru Utara hanya bisa mencukupi kebutuhan Air Bersih Masyarakat sebesar 31,74\% dari jumlah penggunaan air bersih di Kecamatan Banjarbaru Utara. Air bersih yang didapatkan dari hasil pemaenan air hujan di Kecamatan Banjarbaru Utara hanya bisa dijadikan sebagai sumber air bersih tambahan yang bisa digunakan saat musim kemarau dan sumber air utama tidak bisa memenuhi kebutuhan air bersih Domestik Kecamatan Banjarbaru Utara.

\section{KESIMPULAN}

Dari penelitian ini dapat disimpulkan bahwa potensi pemanenan air hujan di Kecamatan Banjarbaru Utara adalah sebagai berikut:

1. Kebutuhan rata - rata harian per orang per hari di Kecamatan Banjarbaru Utara adalah sebesar 200 liter/orang/hari. Jumlah penggunaan air untuk kebutuhan air bersih rumah tangga di Kecamatan Banjarbaru Utara sebesar 4.155.073.297,9 liter/tahun atau sama dengan $4.155 .073,29 \mathrm{~m}^{3} /$ tahun.

2. Volume air hujan yang dapat dipanen di atap - atap rumah di Kecamatan Banjarbaru Utara adalah sebesar 1.318.781.352 liter/tahun atau sama dengan $1.318 .781,35 \mathrm{~m}^{3} /$ Tahun.

3. Potensi pemanenan air hujan di Kecamatan Banjarbaru Utara tidak mampu memenuhi kebutuhan air bersih rumah tangga secara keseluruhan, air bersih hasil pemanenan air hujan hanya bisa dijadikan sebagai sumber air tambahan.

\section{UCAPAN TERIMA KASIH}

Ucapan terima kasih kepada seluruh pihak yang telah membantu kelancaran dalam proses penelitian ini.

\section{DAFTAR PUSTAKA}

Ali, I., Suhardjono, S., \& Hendrawan, A. P. (2017). Pemanfaatan Sistem Pemanenan Air Hujan (Rainwater Harvesting System) di Perumahan Bone Biru Indah Permai Kota Watampone dalam Rangka Penerapan Sistem Drainase Berkelanjutan. Jurnal Teknik Pengairan. Universitas Brawijaya. Malang, 8(1), pp. 26-38. https://jurnalpengairan.ub.ac.id/index.php/ jtp/article/view/303

Amalia, D. N. S., Mardyanto, A., \& Supriyadi, D. B., (2013). Kajian Bak Penampung Tangkapan Air Hujan Sebagai Upaya Penurunan Runoff di Kawasan Perumahan Sukolilo Dian Regency 2 Surabaya. Jurnal Teknik Pomits, 2(1), pp. 2337-3539. 
http://digilib.its.ac.id/public/ITS-paper41098-3309100078-paper.pdf

Aryanto, D. (2017). Potensi Pemanenan Air Hujan (Rainwater Harvesting) untuk Kebutuhan Rumah Tangga di Desa Klunggen Kecamatan Slogohimo Kabupaten Wonogiri. Skripsi. Universitas Muhammadiyah Surakarta. Surakarta. http://eprints.ums.ac.id/58695/26/NASKA H\%20PUBLIKASI.pdf

BPS. (2019). Banjarbaru Utara dalam Angka 2019. Banjarbaru: BPS.

BPS. (2020). Banjarbaru Utara dalam Angka 2020. Banjarbaru: BPS

Brown, Gertson, Colley. (2005). The Texas Manual on Rainwater Harvesting. Austin: Texas Water Development Board.

Efirilianti, V., \& Indrawan, I. (2018). Pemanfaatan Air Hujan untuk Kebutuhan Air Bersih dan Konservasi. Skripsi. Universitas Sumatera Utara. http://repositori.usu.ac.id/handle/1234567 $\underline{89 / 10124}$

Eun-Ha, P., Susilo, G. E., \& Wahono, E. P. (2018). Perencanaan Sistem Pemanenan Air Hujan Skala Rumah Tangga di Korea Selatan. Journal Rekayasa Sipil dan Desain (JRSDD) Fakultas Teknik Universitas Lampung. Bandar Lampung, 6(1), pp. 25-31. https://journal.eng.unila. ac.id/index.php/jrsdd/article/view/790

Kurdi, H., Rusdiansyah, A., Fitriati, U., \& Sumiati, S. (2018). Studi Kebutuhan akan Air Tanah Dangkal di Kecamatan Banjarbaru Utara, Kota Banjarbaru. Prosiding Seminar Nasional Lingkungan Lahan Basah. 3(2), (Banjar Baru, April 2018), (317-320).https://snllb.ulm.ac.id/ prosiding/index.php/snllb-lit/article/ download/73/71

Loebis, J. (1987). Banjir Rencana Untuk Bangunan Air. Departemen Pekerjaan Umum. Badan Penerbit Pekerjaan Umum. Jakarta.

Malik, Y. S., Suprayogi, I., \& Asmura, J. (2016). Kajian Pemanenan Air Hujan Sebagai Alternatif Pemenuhan Air Baku di Kecamatan Bengkalis. Jurnal Online
Mahasiswa Teknik Universitas Riau. Riau, 3(2), pp. 1-13. https://jom.unri.ac.id/index.php/JOMFTE KNIK/article/view/11943

Martha, W. Adidarma, W. (1983). Mengenal Dasar - Dasar Hidrologi. Nova, Bandung.

Maryono, Agus. (2017). Memanen Air Hujan (Rainwater Harvesting). Yogyakarta. Gajah Mada University Press.

Ray K. Linsley, Joseph B. Fransini. (1985). Teknik Sumber Daya Air. Jilid 1. Terjemahan oleh Djoko Sasongko. Erlangga, Jakarta.

Rindang, P. 2018. Analisis Potensi Panen Air Hujan pada Skala Individu sebagai Sumber Air Alternatif di Desa Seriwe, Kecamatan Jerowaru, Lombok Timur. Jurnal Teknik Sipil Universitas Mataram. http://eprints.unram.ac.id/11053/1/Jurnal. pdf

Silvia, C. S., \& Safriana, M. (2018). Analisis Potensi Pemanenan Air Hujan dengan Teknik Rainwater Harvesting untuk Kebutuhan Domestik. Jurnal Teknik Sipil Fakultas Teknik Universitas Teuku Umar, 4(1), pp. 62-73. http://jurnal.utu.ac.id/ jtsipil/article/view/590

Susana, T. Y. (2012). Analisa Pemanfaatan Potensi Air Hujan dengan Menggunakan Cistern sebagai Alternatif Sumber Air Pertamanan pada Gedung Perkantoran Bank Indonesia. Skripsi. Fakultas Teknik. Universitas Indonesia. Depok. http://lib.ui.ac.id/file?file=digital/2030558 7-S42080-Analisa\%20pemanfaatan.pdf

Triatmodjo, Bambang. (2008). Hidrologi Terapan. Beta Offset, Yogyakarta.

Worm, J., \& Hattum, T. V. (2006). Agrodok 43 rd: Rainwater Harvesting for Domestic Use. Wageningen: Agromisa.

Zhang, Y, D. Chen, L. Chen dan S. Ashbolt. (2009). Potential for rainwater use in highrise buildings in Australia cities. Journal of Environmental Management 91: 222-226. 